\title{
Pelatihan Penulisan Comprehension Questions Berbasis High-Order Thinking Skills Bagi Guru Bahasa Inggris SMA/SMK/MA Swasta di Kabupaten Lombok Timur
}

\author{
Lalu Thohir*, Amrullah, Udin, Lalu Jaswadi Putera \\ Program Studi Pendidikan Bahasa Inggris FKIP Universitas Mataram
}

\author{
Article history \\ Received: 25 Desember 2019 \\ Revised: 28 Januari 2020 \\ Accepted: 23 Maret 2020 \\ *Corresponding Author: \\ Lalu Thohir \\ Program Studi Pendidikan \\ Bahasa Inggris FKIP \\ Universitas Mataram \\ Email: thohir@unram.ac.id
}

\begin{abstract}
Critical thinking is a skill which teachers and students need to have in order to be able to solve their problems appropriately. The teachers should incorporate critical thinking in the teaching and learning activities and one of them is through questioning in the form comprehension questions. This social service program was intended to provide teachers with room for improving their capability in generating comprehension questions which are critical-thinking based. This program was held in SMA Islam Al-Badriyah East Lombok and it was attended by 18 English teachers of Private Senior High Schools located in East Lombok district. The activities within this program included presentation, discussion, working in group, presenting group work task and evaluation. From this social service program, it was found that the English teachers participated in all activities enthusiastically, especially, in the discussion and in generating comprehension questions. The questions generated by the participants were not only in the level of lower-order thinking but also in the level of higher-order thinking. Further, the questionnaire result showed that in general the participants appreciated this program and hoped the similar program to come in the future to improve their competency or professionalism in English language teaching.
\end{abstract}

Keywords: competence; program; teacher; thinking; training; questions

Abtrak: Befikir kritis merupakan salah satu keterampilan yang perlu guru dan peserta didik miliki untuk mampu menyelesaikan masalah yang mereka hadapi dengan tepat. Guru dituntut untuk mampu mengintegrasikan keterampilan berfikir kritis dalam kegiatan atau proses pembelajaran dan salah satunya adalah melalui kegiatan tanya-jawab atau penilaian yang diwujudkan dalam bentuk soal (comprehension questions). Kegiatan Pengadian Kepada Masyarakat (PKM) ini bertujuan untuk memberikan ruang bagi guru dalam bentuk pelatihan untuk meningkatkan keterampilan mereka dalam menyusun soal yang berorientasi pada kemampuan berfirkir kritis. Kegiatan PKM ini dilaksanakan di SMA Islam $\mathrm{Al}$ Badriyah Rarang Lombok Timur dan melibatkan 18 guru bahasa Inggris yang tergabung dalam MGMP bahasa Inggris SMA/SMK/MA Swasta kabupaten Lombok Timur. Kegiatan PKM ini berupa pelatihan atau bimbingan teknis dalam penyusunan soal yang diawali dengan pemaparan materi, tanya jawab, kerja kelompok, presentasi hasil kerja kelompok, dan evaluasi kegiatan melalui pengisian angket oleh para peserta. Hasil kegiatan PKM ini menunjukkan bahwa para guru sangat antusius dalam mengikuti rangkaian kegiatan khususnya ketika menyusun soal secara berkelompok, presentasi hasil kerja kelompok dan diskusi. Selain itu didapatkan bahwa soal yang disusun oleh para guru pada waktu pelatihan tidak hanya hanya fokus pada kemampuan berfikir tingkat rendah (Lower-Order Thinking Skills) tapi juga keterampilan berfikir tingkat tinggi (Higher-Order Thinking Skills). Dari hasil angket yang ada, secara umum para guru menyambut 
baik kegiatan ini dan berharap adanya kegiatan serupa yang dapat meningkatkan kompetensi atau profesionalisme dalam pengajaran bahasa Inggris.

Kata Kunci: berfikir; guru; kompetensi; pelatihan; program; soal

\section{PENDAHULUAN}

Era globalisasi yang diwarnai dengan berbagai masalah lingkungan hidup, kemajuan informasi, komunikasi dan teknologi dan kebangkitan industri kreatif menuntut para pendidik untuk memberikan bekal yang memadai kepada para peserta didik sehingga mereka mampu bersaing dan menghadapi tantangan zaman. Oleh karena itu tujuan pembelajaran di sekolah, sesuai dengan apa yang ada pada kurikulum 2013, harus berorientasi atau berbasis pada upaya untuk menjadikan peserta didik siap dan mampu menghadapi permaslahan hidup pada zaman atau abad yang dikenal dengan abad 21.

Terkait dengan isu perkembangan pendidikan di tingkat internasional, kurikulum 2013 dirancang dengan berbagai penyempurnaan, seperti penyempurnaan pada standar penilaian dimana penilaian hasil belajar diharapkan dapat membantu peserta didik untuk meningkatkan kemampuan berpikir tingkat tinggi (Higher Order Thinking Skills/HOTS), karena berpikir tingkat tinggi dapat mendorong peserta didik untuk berpikir secara luas dan mendalam tentang materi pelajaran (Depdikbud, 2017). Oleh karean itu berfikir tingkat tinggi perlu diintegrasikan dalam kegiatan pembelajaran di sekolah. Dalam pembelajaran, Collins (2014) menyatakan bahwa berfikir kritis perlu dilatih atau diajarkan kepada para siswa sehingga mereka mampu menggunakan kemampuan berfikirnya dengan bijak dalam membuat atau mengambil keputusan yang tepat dalam permaslahan yang mereka hadapi

Kegiatan berfikir umumnya dikelompokkkan menjadi dua level, yakni level tingkat rendah atau lebih dikenal dengan istilah LOTS (Lower Oder Thinking Skills) dan level tingkat tinggi atau HOTS (Higher Order Thinking Skills). Pengelompokkan kegiatan berfikir ini merujuk pada taksonomi Bloom yang kemudian disempurnakan oleh Anderson \& Krathwohl (2001) tentang tingkatan kemampuan berpikir yang terdiri dari enam tingkatan, yakni: mengetahui (knowing/C1), memahami (understanding/C2), menerapkan (applying/C3), menganalisis (analyizing/C4), mengevaluasi (evaluating/C5), dan mengkreasi (creating/C6). Kegiatan berfikir C1, C2 \& C3 merupakan kelompok berfikir tingkat rendah, dan kegiatan berifikir C4, C5 \& C6 termasuk dalam kelompok berfikir tingkat tinggi. Pengelompokan tersebut berdasarkan tingkat kesulitan berfikir yang dibutuhkan. Hal ini bermakna bahwa dalam konteks pembelajaran atau penilaian, pertanyaan atau soal pada kategori tingkat paling bawah (C1) meminta pemikiran sederhana untuk menjawabnya, sedangkan pertanyaan dengan kategori tingkat yang lebih tinggi menuntut pemikiran yang lebih kompleks untuk bisa menjawabnya.

Penilaian hasil belajar umumnya dilakukan dengan menggunakan soal-soal yang mengukur kemampuan berfikir. Kemendikbud (2018) menyatakan bahwa soal-soal HOTS sangat direkomendasikan untuk digunakan pada berbagai bentuk penilaian kelas dan ujian sekolah.

Pada UN (Ujian Nasional), para pelajar dihadapkan pada soal-soal yang mencakup ranah kognitif yang menuntut HOTS dan LOTS. Oleh karena itu para siswa di SMP atau SMA perlu dibiasakan atau dilatih untuk menjawab soal-soal, khususnya yang berbasis HOTS, tidak hanya untuk meningkatkan kemampuan mereka menjawab soal ujian tapi juga untuk meningkatkan kemampuan berfikir kritis mereka. Untuk mencapai tujuan-tujuan tersebut, maka guru tentu memiliki peran yang sangat penting. 
Membuat soal atau pertanyaan dari teks berbahasa Inggris untuk tujuan evaluasi formatif ataupun sumatif secara proporsional, soal yang tidak hanya dalam level LOTS tetapi juga HOTS, tentu bukan suatu hal yang mudah. Bukan hanya menuntut kemampuan berfikir yang tinggi tetapi juga kemampuan berbahasa yang memadai. Oleh karenanya, umumnya para guru mengambil/meng-copy paste soal yang sudah ada untuk tujuan penilaian formatif atau summatif. Selain itu, tidak sedikit guru dalam proses penilaian mengajukan pertanyaan tanpa memperdulikan bentuk/type soal apakah termasuk dalam kategori soal yang menuntut berfikir tingkat tinggi atau berfikir tingkat rendah. Mereka juga tidak mempermasalahkan prosentase type soal yang ditulis untuk tujuan penilaian atau evaluasi. Di antara faktor yang jadi penyebabnya adalah kekurang tahuan para guru tentang soal-soal berbasis HOTS dan/atau mereka tidak terbiasa untuk mengembangkan atau menyusun soal-soal penilaian dengan merujuk pada level berfikir secara merata, dari soal-soal yang termasuk dalam kategori LOTS sampai yang termasuk dalam kategori HOTS.

Berdasarkan hal tersebut di atas, kegiatan pengabdian kepada masyarakat (PKM) ini bertujuan untuk memberikan ruang bagi guru untuk berlatih dan melatih diri dalam meningkatkan kecakapan mereka khususnya dalam membuat pertanyaan (comprehension questions) yang baik dan proporsional yang tidak hanya berbasis LOTS tetapi juga HOTS. Dari kegiatan PKM ini, Sumber Daya Manusia (SDM) diharapkan dapat meningkat, dimana dengan meningkatnya kualitas SDM, dalam hal ini para guru, akan berpengaruh pada meningkatnya kualitas SDM, para peserta didik sebagai generasi penerus bangasa. Dalam penelitiannya, Ekaningish (2013) menyimpulkan bahwa pendidikan dan pelatihan memiliki pengaruh yang signifikan pada peningkatan kualitas sumber daya aparatur, meskipun pengaruhnya secara tidak langsung. Dia menyatakan bahwa pendidikan dan pelatihan memberikan pengaruh terhadap kompetensi aparatur dan peningkatan kompetensi tersebut sangat berpengaruh terhadap peningkatan sumber daya aparatur.

Selain itu, kegiatan pengabdian kepada masyarakat ini diharapkan tidak hanya sebatas terwujudnya pelaksanaan Tri Dharma perguruan tinggi tetapi juga sebagai upaya untuk menjalin kerja sama antara perguruan tinggi dan sekolah, yang dalam hal ini, SMA/SMK/MA, yang merupakan sumber mahasiswa bagi perguruan tinggi.

\section{METODE}

Kegiatan Pengabdian Kepada Masyarakat (PKM) ini diterapkan dengan metode pelatihan dan/bimbingan teknis yang meliputi penyajian materi (ceramah), diskusi, praktik penyusuan soal, presentasi hasil kerja kelompok dan kemudian evaluasi.

Materi pelatihan dipersiapkan dengan mengadaptasi bahan dari Modul Penyusunan Soal Higher Order Thinking Skills (HOTS) yang diterbitkan oleh Direktorat Pembinaan SMA Direktorat Jenderal Pendidikan Dasar dan Menengah Departemen Pendidikan dan Kebudayaan (2017) dan dari Buku Penilaian Berorientasi HOTS yang diterbitkan oleh Direkorat Jendral Guru dan Tenaga Kependidikan Kemendikbud (2018). Materi pelatihan meliputi pengertian soal-soal HOTS dan level kognitif, karakteristik soal-soal HOTS, peran soal-soal HOTS dalam penilaian, bentuk/macam-macam soal (comprehension questions) dan praktik penyusunan soal.

Kegiatan PKM ini dilaksanakan di SMA Islam Al-Badriyah Lombok Timur pada hari Kamis, 29 Agustus 2019 dan dihadiri oleh 18 orang guru Bahasa Inggris yang tergabung pada MGMP (Musyawarah Guru Mata Pelajaran) bahasa Inggris SMA/SMK/MA Swasta Lombok Timur. 


\section{HASIL DAN PEMBAHASAN}

Dari kegiatan PKM yang sudah dilaksanakan berupa pelatihan penulisan soal (comprehension questions) berbasis HOTS bagi guru-guru bahasa Inggris SMA/SMK/MA swasta di Lombok Timur, terdapat beberapa hal yang dapat dideskripsikan, antara lain:

1. Sesuai rencana dan undangan, kegiatan ini seyogyanya akan dihadiri oleh 25 orang guru, namun karena sebagian guru ada kegiatan lain di sekolah mereka dan juga alasan lainnya, maka yang berkesempatan hadir adalah sebanyak 18 guru.

2. Berdasarkan hasil angket dalam bentuk skala (Gambar 1) yang diperoleh dari respon para guru terkait kegiatan pengabdian kepada masyarakat ini, dapat disampaikan bahwa:

a. Pada kategori 1, terkait sarana-prasarana pelatihan, sebagian besar (13 orang/72,22\%) menyatakan kalau sarana-perasarana dalam kegiatan pengabdian pada masyarakat ini adalah "baik", sedangkan sisanya (5 orang/27,78\%) menyatakan "sangat baik".

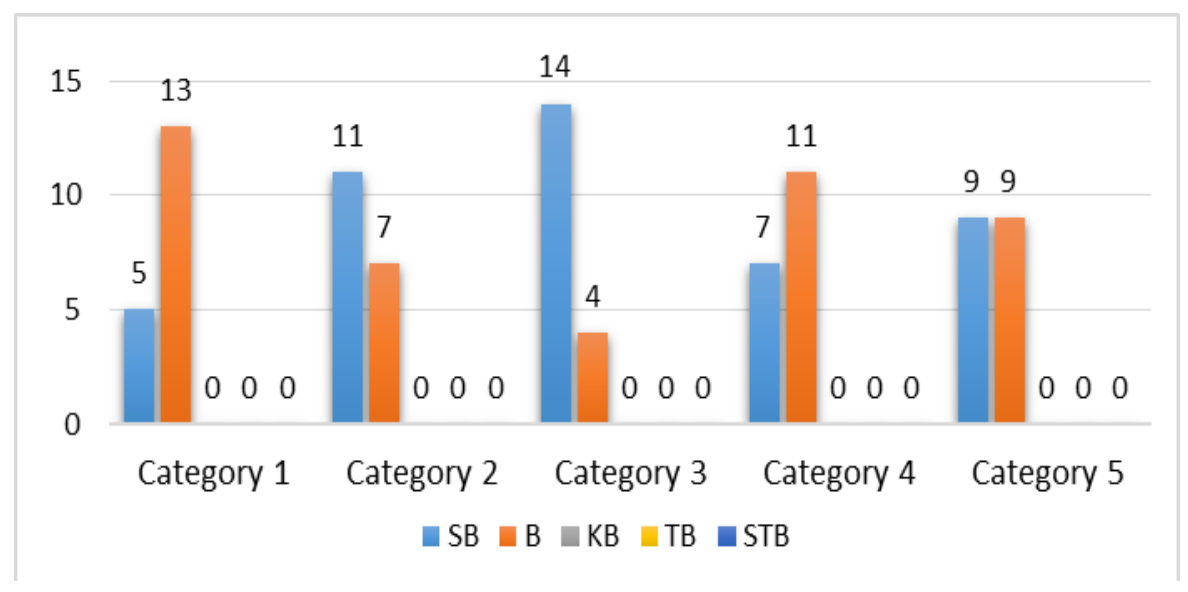

Gambar 1. Grafik angket penilaian peserta terhadap kegiatan pengabdian kepada masyarakat.

b. Kategori 2 adalah terkait layanan selama kegiatan pelatihan. Pada kategori ini, sebagian besar peserta (11 orang/61,11\%) menyatakan "sangat baik", dan 7 orang $(38,89 \%)$ menyatakan "baik".

c. Pada kategori 3, tentang materi pelatihan, sebagian besar peserta (14 orang/77,78\%) menyatakan "sangat baik", dan 4 orang $(22,22 \%)$ menyatakan "baik".

d. Kategori 4 adalah tentang sistematika kegiatan pelatihan. Dalam hal ini, sebagian besar, 11 orang $(61,11 \%)$ menyatakan "baik", dan 7 orang lainnya $(38,89 \%)$ menyatakan "sangat baik"

e. Pada kategori 5, terkait konsumsi pelatihan, 9 orang (50\%) menyatakan "sangat baik" dan 9 orang lainnya (50\%) menyatakan "baik".

3. Sedangkan dari hasil angket terbuka (isian) yang menyangkut kesan terkait pelatihan yang sudah dilaksanakan dan harapan untuk kegiatan serupa jika diadakan pada masa yang akan datan, respon para peserta dapat disimpulkan bahwa:

a. Sebagian besar peserta menyatakan bahwa kegiatan seperti ini sangat bermanfaat karena dapat menambah pengetahuan dan wawasan bagi para guru yang secara tidak langsung dapat meningkatkan mutu pendidikan, oleh karenanya mereka berpendapat kalau kegiatan seperti ini sangat penting untuk dilakukan. Sebagian lainnya menyatakan bahwa pelaksanaan kegiatan 
pelatihan ini berjalan dengan baik dengan metode penyampaian yang mudah dipahami dan menyenangkan.

b. Diantara harapan yang disampaikan oleh para peserta kegiatan ini adalah terkait adanya tindak lanjut dari kegiatan serupa dengan alokasi waktu yang lebih banyak khususnya untuk pelatihan dan didukung oleh materi yang lebih banyak dan bervariasi. Selain itu mereka juga berharap agar kegiatan serupa dapat melibatkan peserta atau guru bahasa Inggris dengan jumlah yang lebih banyak.

4. Dari hasil observasi selama kegiatan pelatihan, khususnya selama kegiatan/kerja kelompok dalam menyusun soal dan presentasi hasil kerja (Gambar 1), dapat dinyatakan kalau para peserta sangat antusius dalam mengerjakan tugas secara berkelompok dan berdiskusi terkait soal-soal (comprehension questions) yang mereka buat.

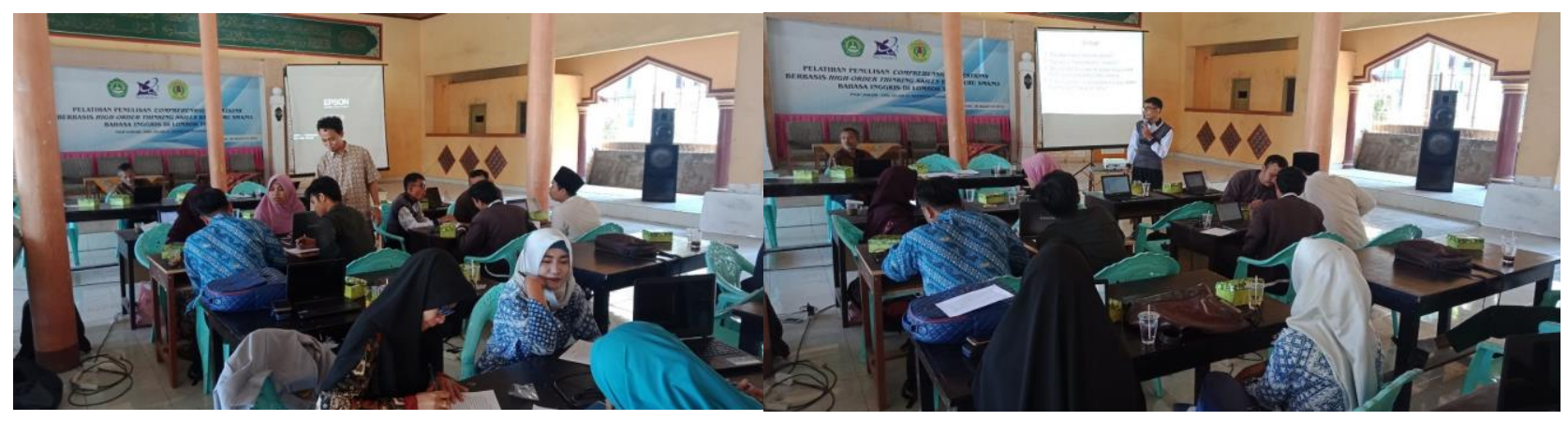

Gambar 2. Kegiatan Kerja Kelompok (kanan) dan Presentasi Hasil Kerja Kelompok (kiri)

\section{KESIMPULAN DAN SARAN}

Kegiatan PKM dalam bentuk pelatihan penulisan soal (comprehension questions) berbasis HOTS untuk para guru bahasa Inggris SMA/SMK/MA Swasta di kabupaten Lombok Timur telah dilaksanakan dengan baik. Para peserta menyambut baik kegiatan tersebut dan hal ini dapat dilihat dari antusiasme mereka selama kegiatan dan juga dari respon yang mereka berikan terhadap sejumlah pernyataan terkait kegiatan pengabdian ini. Para peserta menyatakan bahwa kegiatan seperti ini sangat bermanfaat karena dapat menambah pengetahuan dan wawasan meraka yang secara tidak langsung dapat meningkatkan mutu pendidikan. Mereka berharap adanya tindak lanjut dari kegiatan serupa dengan alokasi waktu yang lebih banyak, materi yang lebih bervariasi dan juga peserta yang lebih banyak.

\section{Ucapan Terima Kasih}

Pelaksanaan kegiatan PKM ini tidak terlepas dari bantuan sejumlah pihak. Oleh karena itu, tim PKM menyampaikan ucapan terima kasih kepada Lembaga Penelitian dan Pengabdian Pada Masyarakat Universitas Mataram yang telah membantu dalam pembiayaan kegiatan ini dan kepada kepala SMA Islam Al-Badriyan beserta staff yang telah memfasilitasi dalam pelaksanaan kegiatan ini..

\section{DAFTAR PUSTAKA}

Anderson, L.W., and Krathwohl, D.R. 2001. A Taxonomy of Learning, Teaching, and Assessing: A Revision of Bloom's Taxonomy of Educational Objectives. New York: Longman. 
Collins, R. 2014. Skills for 21st Century: Teaching Higher-Order Thinking. Curriculum \& Leadership Journal. vol. 12.

Depdikbud. 2017. Modul Penyusunan Soal Higher Order Thinking Skill (HOTS). Direktorat Pembinaan SMA Direktorat Jenderal Pendidikan Dasar dan Menengah.

Ekaningsih, A.S. 2013. Peran Pendidikan dan Pelatihan serta Kompetensi dalam Upaya Peningkatan Kualitas Sumber Daya Aparatur. Jurnal Borneo Administrator. 9(2)

Kemendikbud. 2018. Buku Penilaian Berorientasi Higher Order Thinking Skills. 2018. Program Peningkatan Kompetensi Pembelajaran Berbasis Zonasi. Direktorat Jendral Guru dan Tenaga Kependidikan. 